\begin{tabular}{c} 
Volume and Issues Obtainable at Center for Sustainability Research and Consultancy \\
Journal of Business and Social Review in Emerging Economies \\
ISSN: 2519-089X (E): 2519-0326 \\
Volume 5: No. 1, June 2019 \\
CSRᄃ \\
Journal homepage: www.publishing.globalcsrc.org/jbsee \\
\hline
\end{tabular}

\title{
Consumer Perceived Value in Understanding Herbal Medicine Consumption: A Conceptual Model
}

\author{
${ }^{1}$ Adeline Y. L. Tam, ${ }^{2}$ Rohaizat Baharun, ${ }^{3}$ Zuraidah Sulaiman \\ ${ }^{1}$ Azman Hashim International Business School, Universiti Teknologi Malaysia, Malaysia \\ Email address: adelinetamyl@gmail.com
}

\begin{tabular}{|c|c|}
\hline ARTICLE DETAILS & ABSTRACT \\
\hline History & \multirow{9}{*}{$\begin{array}{l}\text { Introduction: Facing extensive competition, the marketers and producers } \\
\text { of herbal medicine products (HMP) should pay more concern to } \\
\text { maintaining repeat purchases and keeping customers loyal with their } \\
\text { products. } \\
\text { Purpose: This study aims to (1) propose the dimensions of consumer } \\
\text { perceived value (CPV) for HMP; and (2) propose a conceptual framework } \\
\text { to test CPV influences on consumption behavior, repurchase intention and } \\
\text { customer loyalty. } \\
\text { Methodology: The value dimensions of HMP included functional value } \\
\text { (price), functional value (quality), social value, emotional value (feeling), } \\
\text { and conditional value (holistic treatment value). CPV was proposed as an } \\
\text { antecedent of repurchase intention and customer loyalty. }\end{array}$} \\
\hline Revised format: May 2019 & \\
\hline Available Online: June 2019 & \\
\hline & \\
\hline Teachers' Herbal Medicine & \\
\hline & \\
\hline Customer Loyalty, Consumption & \\
\hline Behavior & \\
\hline JEL Classif & \\
\hline & $\begin{array}{l}\text { Implications: A conceptual framework with a second-order multi- } \\
\text { dimensional CPV as the antecedent of repurchase intention and customer } \\
\text { loyalty was proposed. This article proposed a conceptual framework to } \\
\text { analyze the influence of value dimensions on HMP. This could provide } \\
\text { useful theoretical insights into the values perceived in HMP consumption } \\
\text { behavior. }\end{array}$ \\
\hline
\end{tabular}

(C) 2019 The authors, under a Creative Commons AttributionNonCommercial 4.0

Corresponding author's email address: adelinetamyl@gmail.com

Recommended citation: Tam, Y. L. A., Baharun, R. and Sulaiman, Z. (2019). The Consumer Perceived Value in Understanding the Consumption of Herbal Medicine: A Conceptual Model. Journal of Business and Social Review in Emerging Economies, 5 (1), 9-18

DOI: $10.26710 /$ jbsee.v5i1.614

\section{Introduction}

Herbal medicine products (HMP) is referred as 'medicinal products containing exclusively herbal active substances that differ from chemically defined substances in several aspects; most notably, they consist of complex multicomponent mixtures resulting from, e.g., extraction of plant parts such as roots and leaves' (Du et al., 2014: 218). HMP can be consumed in various forms, such as pure herbs, processed herb-based applications, traditional herbs pharmaceuticals products, and herb supplements (Rezai et al., 2013; Wu, Wang, \& Kennedy, 2013). HMP is not part of conventional or western medicine but is categorized as a Complementary health Approaches (CHA). HMP is frequently used to prevent illness or maintain health rather than to treat illnesses (Craft et al., 2015; Duffy et al., 2017). HMP is the most commonly used CHA in many countries such as the United Kingdom (Posadzki et al., 2013), Taiwan (Chang, Liu, \& Chen, 2014), and Malaysia (IPH, 2015). The market for HMP has grown tremendously in the last few years. The global market for HMP (composed of tablets, capsules, powders and 
extracts), grew by 13 per cent from $\$ 63.05$ billion (USD) in 2014 to $\$ 71.19$ billion (USD) in 2016 (Hexa Research, 2017).

In response to the high demand for HMP, HMP producers should pay more attention to ensure customers satisfaction. Satisfied customers were willing to buy more and were more loyal to the company (Chiu et al., 2014). Moreover, the costs of attracting repeat purchasers is less than new customers (Chang, Backman, \& Huang, 2014). To encourage repeat purchases and build up a loyal customer base, it is important to understand how consumers value the HMP and whether their value perceptions influence decisions to repeat a purchase and to be loyal to a HMP. Consumer Perceived Value (CPV) was found to be associated with higher customer satisfaction, who in turn are likely to have higher repurchase intention and are more loyal to a company (Atulkar \& Kesari, 2017).

Few studies have investigated the influence of CPV on determining CHA consumption, particularly for HMP. Dodds, Bulmer, \& Murphy (2014) has, applied a qualitative method, provided a comprehensive understanding on $\mathrm{CPV}$ of CHA consumers. However, they investigated CPV by assuming that the various approaches under the umbrella of CHA was a single entity and that consumer decision-making processes did not vary for different CHA modalities. Although some studies focused on the HMP use, they did not examine the HMP use for health maintenance and rather focused more on health seeking groups (Charaf et al., 2015; Tangkiatkumjai et al., 2014). Therefore, influence of CPV on HMP use among the healthy population is worth investigating.

This study proposed (1) to developed multi-dimensions CPV for HMP, and (2) a conceptual framework to test the influences of CPV on consumption behavior (repurchase intention and customer loyalty) to provide a better understanding of HMP consumption. This paper is organized as follows. The following section outlines a literature review of CPV and consumption behavior. Next, a proposed conceptual framework is presented. The final section concludes this paper with implications and limitations.

\section{Literature Review}

\subsection{Consumer Perceived Value and Theory of Consumption Value (TCV)}

Value is abstract, multi-faceted, and complex, and having different meanings for consumers, researchers, and even practitioners (Gallarza \& Gil-saura, 2006). CPV is an 'interactive relativistic preference experience; the evaluation of some object (product/service) by some subject (consumer)' (Holbrook, 1999:5). In this paper, CPV is defined as customer utility assessments that are subject to experience and are inherent to or linked with the consumption of products or services. (Woodruff, 1997; Zeithaml, 1988).

This study used a multidimensional approach, which utilizes several interrelated dimensions, combining both utilitarian and hedonic aspects to capture CPV. Leroi-Werelds et al. (2014) concluded that multi-dimensional, consequence-based methods were the best because they had the best predictive ability and fit the concept of 'valuein-use'. Consumer behavior is a function of various value dimensions (Gonçalves, Lourenço, \& Silva, 2016). Thus, Theory of Consumption Value (TCV) (Sheth et al., 1991), which theorizing five value dimensions (functional, social. emotional, epistemic, and conditional) for a multi-dimensional CPV analysis, were used in this study. TCV proposed that CPV influences consumer purchase choices and that the most discriminating value in a purchase decision, product type selection, or branding decision, even for the same product, were not identical (Sheth et al., 1991).

TCV value dimensions were recognized as 'provides the best foundation for extending existing value constructs' (Sweeney \& Soutar, 2001: 205). TCV has been applied to many contexts, such as team sport games (Kunkel, Doyle, \& Berlin, 2017), green products (Gonçalves et al., 2016; Suki, 2016), online retailing (Carlson, O'Cass, \& Ahrholdt, 2015), and mobile services (Yang \& Lin, 2017). Reviewing these studies could provide additional understanding on CPV influence on consumption behavior. Table 1 summarizes the influence of value dimensions in term of beta coefficient value $(\beta)$, on dependent variables (buying behavior, intention to purchase or use, and loyalty) in the literature from the year 2011. Most studies that applied TCV did not used all five dimensions in their studies, instead using the three most crucial dimensions, FV, SV, and EV. Although most studies used first order value-dimensions to investigate the direct relationships between CPV and dependent variables, some other researchers (e.g. Kunkel et al., 2017; Carlson, Rosenberger, \& Rahman, 2016) used a second-order CPV to reflect $\mathrm{CPV}$ as a multi-dimensional construct. 
Table 1 Relationship between perceived value and dependent variable

\begin{tabular}{|c|c|c|c|c|c|c|c|c|c|c|c|}
\hline \multirow[b]{2}{*}{ Author } & \multirow{2}{*}{$\begin{array}{l}\beta- \\
\text { value } \\
\\
8\end{array}$} & \multicolumn{6}{|c|}{$\beta$-value of Value Dimensions } & \multicolumn{3}{|c|}{$\begin{array}{l}\text { Dependent } \\
\text { Variable }\end{array}$} & \multirow[b]{2}{*}{ Note } \\
\hline & & $\sum_{i}^{2}$ & $\sum_{1}^{2}$ & $\vec{s}$ & 齐 & $\frac{2}{\text { II }}$ & $z$ & $\begin{array}{l}\frac{\pi}{8} \\
0 \\
00 \\
0 \\
0 \\
0\end{array}$ & 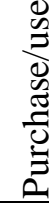 & 吾 & \\
\hline$\wedge$ Kim et al., 2011 & & $\mathrm{Y}$ & $\mathrm{Y}$ & $\begin{array}{l}\text { a. } 4 \\
7 * * \\
\text { bY }\end{array}$ & $\begin{array}{l}.60 \\
* *\end{array}$ & & & & $\mathrm{X}$ & & $\begin{array}{l}\text { aSelf-image expression; } \\
\text { bRelationship support }\end{array}$ \\
\hline ^Koller et al., 2011 & & .01 & $\begin{array}{l}.55 \\
* *\end{array}$ & $\begin{array}{l}.22 \\
* *\end{array}$ & $\begin{array}{l}.20 \\
* *\end{array}$ & & & & & $\mathrm{X}$ & \\
\hline${ }^{\wedge}$ Wang et al., 2013 & & $.13^{*}$ & & $\begin{array}{l}.09 \\
*\end{array}$ & $\begin{array}{l}.29 \\
* *\end{array}$ & $\begin{array}{l}.36 \\
* *\end{array}$ & $\mathrm{aY}$ & & $\mathrm{X}$ & & aIndirect \\
\hline Chiu et al., 2014 & & $.45^{* *}$ & & & $\begin{array}{l}.31 \\
* *\end{array}$ & & & & $\mathrm{aX}$ & & aRepurchase intention \\
\hline Goh et al., 2014 & & $.25 * *$ & & $\begin{array}{l}.29 \\
* *\end{array}$ & $\begin{array}{l}.17 \\
*\end{array}$ & $\begin{array}{l}.18 \\
* *\end{array}$ & .12 & & $\mathrm{X}$ & & \\
\hline ^Seyal et al., 2014 & & .12 & & $\begin{array}{l}.24 \\
* *\end{array}$ & .14 & & -.13 & & & $\mathrm{X}$ & \\
\hline $\begin{array}{l}\wedge \text { Carlson, et al., } \\
2015\end{array}$ & $\begin{array}{l}\text { F } \\
\text { a.30* } \\
* \\
\text { b.45 } \\
* *\end{array}$ & $\mathrm{Y}$ & $\mathrm{Y}$ & & $\mathrm{Y}$ & & & & & $X$ & $\begin{array}{l}\text { aAustralian sample; } \\
\text { bFrance sample; }\end{array}$ \\
\hline $\begin{array}{l}\text { Gallarza et al., } \\
2015\end{array}$ & & Y & $\begin{array}{l}.20 \\
* *\end{array}$ & & $\begin{array}{l}.14 \\
* *\end{array}$ & & & & & $X$ & \\
\hline Carlson et al., 2016 & $\begin{array}{l}\text { F.45 } \\
* *\end{array}$ & Y & $\mathrm{Y}$ & $\mathrm{Y}$ & $\mathrm{Y}$ & $\mathrm{Y}$ & & & $X$ & & \\
\hline Choi et al., 2016 & R Y & & $\mathrm{Y}$ & $\mathrm{Y}$ & $\mathrm{Y}$ & & & & $\mathrm{X}$ & & \\
\hline $\begin{array}{l}\text { Gallarza et al., } \\
2016\end{array}$ & & & & & $\begin{array}{l}.16 \\
* *\end{array}$ & & & & & $X$ & \\
\hline ^Suki, 2016 & & .06 & $\begin{array}{l}.20 \\
*\end{array}$ & $\begin{array}{l}.35 \\
*\end{array}$ & -.01 & .21 & .04 & $\mathrm{aX}$ & & & aPurchase volume \\
\hline Sun et al., 2016 & & & $\begin{array}{l}.21 \\
* *\end{array}$ & $\begin{array}{l}.53 \\
* *\end{array}$ & $\begin{array}{l}.31 \\
* *\end{array}$ & & & & $\mathrm{X}$ & & \\
\hline $\begin{array}{l}\text { Willems et al., } \\
2016\end{array}$ & & $.08^{*}$ & $\begin{array}{l}\mathrm{a}- \\
.03 \\
\mathrm{~b} .0 \\
5\end{array}$ & $\begin{array}{l}.20 \\
* *\end{array}$ & $\begin{array}{l}.34 \\
* *\end{array}$ & & & & $\mathrm{cX}$ & & $\begin{array}{l}\text { aService excellence; } \\
\text { bProduct excellence; } \\
\text { cRepurchase intention }\end{array}$ \\
\hline $\begin{array}{l}\text { Zainuddin et al., } \\
2016\end{array}$ & & Y & & $\begin{array}{l}.07 \\
* \\
\end{array}$ & $\begin{array}{l}.10 \\
*\end{array}$ & & & & $\mathrm{X}$ & & $\begin{array}{l}\text { FV only has a significant } \\
\text { relation with satisfaction }\end{array}$ \\
\hline $\begin{array}{l}\text { ^Khan \& Mohsin, } \\
2017\end{array}$ & & $\begin{array}{l}.19 * \\
*\end{array}$ & -.09 & $\begin{array}{l}.26 \\
* *\end{array}$ & $\mathrm{Y}$ & $\begin{array}{l}- \\
.17 \\
*\end{array}$ & $\begin{array}{l}- \\
.18 \\
* *\end{array}$ & $\mathrm{aX}$ & & & aConsumer choice \\
\hline $\begin{array}{l}{ }^{\wedge} \text { Kunkel et al., } \\
2017\end{array}$ & $\begin{array}{l}\mathrm{R} \\
\text { a. } 44 * \\
\text { b.57 } \\
*\end{array}$ & $\begin{array}{l}\text { a. } 27 * \\
* \quad b- \\
.07\end{array}$ & $\begin{array}{l}\text { a. } 4 \\
5 * * \\
\text { b. } 3 \\
4 * *\end{array}$ & $\begin{array}{l}\text { a. } 2 \\
6^{* *} \\
\text { b. } 4 \\
5^{* *}\end{array}$ & $\begin{array}{l}\text { a.3 } \\
7 * * \\
\text { b. } 1 \\
4\end{array}$ & $\begin{array}{l}\text { a.0 } \\
4 \# \\
\text { b- } \\
.27 \\
* *\end{array}$ & & $\mathrm{cX}$ & & & $\begin{array}{l}\text { aStudy 1; bStudy 2; } \\
\text { cCommitment } \\
\text { maintaining relationship }\end{array}$ \\
\hline$\wedge$ Yang \& Lin, 2017 & & -.07 & .32 & a.2 & c. 1 & .15 & & & $X$ & & aRelationship \\
\hline
\end{tabular}




\begin{tabular}{|c|c|c|c|c|c|c|}
\hline & $* *$ & $\begin{array}{l}4 * * \\
\text { b- } \\
.07\end{array}$ & $\begin{array}{l}5^{*} \\
\text { d- } \\
.10\end{array}$ & $* *$ & & $\begin{array}{l}\text { maintenance; bCreation; } \\
\text { cRelaxation;dPlayfulness }\end{array}$ \\
\hline Yang et al., 2018 & $\begin{array}{l}\mathrm{a}- \\
.17 \\
* * \\
\mathrm{~b}- \\
.04\end{array}$ & $\begin{array}{l}\text { a.5 } \\
7 * * \\
\text { b. } 3 \\
1 * *\end{array}$ & & & $\mathrm{X}$ & $\begin{array}{l}\text { aUSA sample; } \\
\text { bChina sample }\end{array}$ \\
\hline
\end{tabular}

Note: ^Applied TCV; CPV is second-order construct: Formative construct (F) and Reflective construct (R); ${ }^{*} \mathrm{p}<.05$; $* * \mathrm{p}<.01 ; \mathrm{Y}-\beta$-value not available; $\mathrm{X}$ - dependent variable

TCV proposes that value dimensions are independent and contribute differently to various consumer choice situations, in which value dimensions are not interchangeable, do not share common theme and might not be covary with each other, fulfilling the formative construct criteria of Jarvis, Mackenzie, \& Podsakoff (2003). Except for Kunkel et al. (2017) and Choi, Ko, \& Kim (2016), past studies (Carlson et al., 2015; Carlson et al., 2016) applied first order reflective constructs for value dimensions and second order formative construct of CPV. With one exceptional (Choi, Ko, \& Kim, 2016), the hierarchical CPV was found to relate positively to purchase intention and loyalty with $\beta$-values ranging between .30 and .67 (Carlson et al., 2015; Carlson et al., 2016; Kunkel et al., 2017).

\subsubsection{Functional value}

Functional value (FV) are the perceived benefits for a products functional, utilitarian or physical performance, which may be derived from product attributes (reliability, durability, and price) (Sheth et al., 1991). In contrast to TCV that proposed FV as a single dimension, Sweeney \& Soutar (2001) proposed that there are two types of FV, price/value for money and performance/quality, which are distinct from one another. The price/value for money dimension (FVP) is the utility derived from a product due to a reduction in its perceived short term and longer term costs while performance/quality (FVQ) is the utility derived from the perceived quality and expected performance of a product (Sweeney \& Soutar, 2001). Dodds et al. (2014) found that care quality and treatment efficiency were two most important value dimensions sought by CHA consumers. Similarly, Pevec \& Pisnik (2016) pointed out that both price and perceived quality were two important value dimensions of health service.

Except for two studies (Seyal et al., 2014; Kim, Gupta \& Koh, 2011), FV predicted significantly the dependent variables (Table 1). Most studies analyzed the FVP and FVQ, separately and concluded that the either one of FV dimensions was positively associated with the dependent variables (Yang \& Lin, 2017; Chiu et al., 2014), with $\beta$ values ranging between .08 and .55. The influences of FVP and FVQ on dependent variables were contradicting. In those studies that confirmed a positive relationship between FVQ and behavior or intention, FVP was found to be insignificant (Suki, 2016; Yang \& Lin, 2017). Contrarily, those studies that confirmed FVP had a significant positive relationship with the dependent variables found that FVQ was insignificant (Khan \& Mohsin, 2017; Willems, Leroi-Werelds \& Swinnen, 2016). Undoubtedly, FV is an important value perceived by CHA users (Dodds et al., 2014). Nevertheless, past studies did not provide evidence on the influence of FVP compared to FVQ in determining repurchase intention and loyalty for HMP. This study proposed to study the perceived value of FVP and FVQ in relation to HMP consumption behaviors (repurchase intention and loyalty) to allow for a comparison between the influences of FVP and FVQ on HMP consumption.

\subsubsection{Social value}

Social value (SV) is defined as the perceived utility derived from a product's ability to enhance associations with one or more specific social group(s) and social self-concepts (Sheth et al., 1991). Ghazali et al. (2017) noted that as consumers tend to buy a product that follow society's perception, social appeal is influential in developing consumer product preferences. Likewise, SV is crucial to consumers by enhancing individual self-concept and selfidentification as an opinion leader to use healthcare services (Zainuddin et al., 2016). Using CHA, allowed users to gain sense of self via feelings of well-being (Dodds et al., 2014).

SV was found to be significantly and positively associated with consumer choice (Khan \& Mohsin, 2017), intention to purchase or use (Yang \& Lin, 2017) and customer loyalty (Seyal et al., 2014) with $\beta$-values ranging between .07 and .53 in all studies (Table 1). Although some researchers (Yang \& Lin, 2017; Kim et al., 2011) proposed two sub-dimensions for social value, these sub-dimensions were only appropriate for the respective research area only. 
The social value dimension is perceived by consumers as a crucial value dimension. This study proposed to investigate social value influences on HMP consumer repeat purchase intention and loyalty.

\subsubsection{Emotional value}

Emotional value (EV), also known as hedonic or experiential value, is the utility derived from feelings or various affective states, such as calm, peaceful mind and relaxed (Sweeney \& Soutar, 2001). Although Holbrook (1999) suggested that EV should include two sub-dimensions, feeling and aesthetics, TCV proposed EV as a single dimension that most concerned with feelings or affective states. The typical personal and emotional experiences of individuals (positive, negative, or mixed) influence an individual's EV (feeling or affective arousal) (Suki, 2016).

Consumers who expected to receive a desire EV, will proceed with the consumption experience. Table 1 recorded only the EV of feeling tested in past studies. EV has a significant positive direct relationship with intention to purchase or use (Yang \& Lin, 2017; Zainuddin et al., 2016) and customer loyalty (Gallarza et al., 2016) ( $\beta$-values ranging from .10 to .60) in all but four studies (Khan \& Mohsin, 2017; Choi et al., 2016; Suki, 2016; Seyal et al., 2014) (Table 1). Concern for EV is critical for health care products (Zainuddin et al., 2016) and CHA (Dodds et al., 2014). Hence, this study included EV to investigate the influences of CPV on repeat purchase intention and loyalty of HMP consumers.

\subsubsection{Epistemic value}

Epistemic value (EPV) refers to a product's capacity to arouse curiosity, provide novelty, and/or satisfy a desire for knowledge (Sheth et al., 1991). Not only will new experience provide EPV, changing to new alternatives will also provide EPV because customers might be bored or satiated with current brands, be curious, and have a desire to learn (Sheth et al., 1991; Yang \& Lin, 2017). Lin \& Huang (2012) pointed out that consumers seek novelty as 'to create a database of potentially useful knowledge' which may be importance in the future and may serve to improve problem-solving skills. Knowledge promotes attitudes and predisposes behavior (Suki, 2016).

Relatively fewer studies have tested EPV. The influences of EPV were inconsistent in past studies (Table 1). EPV was found to positively and significantly predict buying behavior (Suki, 2016) and use or purchase intention (Yang \& Lin, 2017; Goh, Suki, \& Fam, 2014; Wang, Liao, \& Yang, 2013). In contrast, EPV was found to be negatively related with consumer choice (Khan \& Mohsin, 2017) and commitment to maintain relationships (Kunkel et al., 2017). A likely explanation for these inconsistencies is that EPV arise from the satisfaction of curiosity, the provision of novelty, or acquisition of knowledge, which were related to use of new product or alternatives, but negatively related to familiar products or brands. For consumers who are loyal to a product or brand, they might be satisfied with a product value dimensions other than EPV. Since EPV was negatively related with decisions to maintain long-term relationships (Kunkel et al., 2017), EPV is excluded in this study.

\subsubsection{Conditional value}

Conditional value (CV) arises from a specific situation or set of circumstances faced by a consumer that enhance FV or SV (Sheth et al., 1991). These specific situations or circumstances might related to particular time (seasonal), place, or personal condition (Lin \& Huang, 2012). CV arises when products and services were used in these specific situation or circumstances (Gonçalves et al., 2016). CV is always designed to reflect situations related to the type of product or service surveyed in a study. For example, in a mobile application usage context, the CV was related to the utility that arises from the use of an application in a specific environment (when lost), time, place, or other constraints (Wang et al., 2013). While purchasing a green product, the CV of the green product is compared against conventional products under specific conditions, such as worsening environmental conditions and the availability of green products in general (Suki, 2016).

CV has been tested in few studies, Khan \& Mohsin (2017) was the only study found that CV significantly and negatively predicted consumer choice. A possible explanation for insignificant results was that the condition applied in their study might be perceived as less valuable to respondents. Hence, it is vital to identify conditional variables that fit a study's context and purpose. A possible condition for personal perception towards CHA use, an appreciation of holistic treatments.

Holistic treatment value a CV of HMP, which is appreciated by both CHA and HMP users (Dodds et al., 2014; Rhee, Ng, \& Dusek, 2017). Holistic orientation emphasis on treating the whole person (rather than symptomatic approach) (Ganasegeran, Rajendran, \& Al-Dubai, 2014). Dodds et al. (2014) pointed out that a majority of CHA 
users appreciating holistic value, which involved the integration of whole (mind, body and spirit). Ganasegeran, Rajendran, \& Al-Dubai (2014) also found that an appreciation for holistic treatments was significantly related to CHA use. And hence, this study proposed to include holistic treatment value as a CV of HMP.

\subsubsection{Multi-dimensional Consumer Perceived Value}

The literature revealed that HMP users appreciate the multiple dimensions of CPV (Goh et al., 2014; Khan \& Mohsin, 2017; Suki, 2016). As proposed earlier, the dimensions that should be included in CPV are FVP, FVQ SV, $\mathrm{EV}$, and $\mathrm{CV}$. These five value dimensions constituted the first order reflective constructs of CPV. EPV are not tested in this study. CPV is a second order formative construct (Carlson et al., 2016) in line with TCV's proposition that these value dimensions are independent and contribute differently to various consumer choice situations. Accordingly, the following proposition was proposed:

Proposition 1: FVV, FVQ, SV, EV, and CV formed the reflective first order components of CPV. CPV is a formative second-order construct.

\subsection{Consumption Behaviors}

CPV in this study focused on consumer value perception after product used among HMP users. Thus, this study proposed to examine the HMP consumer behavior using two aspects, repurchase intention and customer loyalty, which are relevant to building long-term relationships between producers and customers.

\subsubsection{Repurchase intention}

Intention is an individual's subjective probability to perform a specific behavior (Fishbein \& Ajzen, 1975). The Theory of Planned Behavior (Ajzen, 1991) proposed that intention is the only predictor of behavior. Repurchase intention is referred to as 'the individual's judgement about buying again a designated service from the same company, taking into account his or her current situation and likely circumstances' (Hellier et al., 2003: 1764). A repeat customer's decision to buy the same product or service again is influenced by perceived value from past purchasing experiences, which encompasses multiple value dimensions.

The literature confirmed that CPV is an antecedent of purchase intention, in which all CPV dimensions except for conditional value were found to positively related with purchase intention (Carlson et al., 2016; Yang \& Lin, 2017; Goh, Suki, \& Fam, 2014). However, limited studies have examined the influence of CPV on repurchase intention among the CHA users. Chiu et al. (2014) confirmed that utilitarian and hedonic value were significantly associated with repurchase intention, while Willems et al. (2016) provided evident that FVP (efficiency), SV, and EV (aesthetics and play) predicted repurchase intention but FVQ (product and service excellence) did not predicted repurchase intention. This study examined the influence of second-order formative CPV, with FVP, FVQ, SV, EV, and CV as the first-order, on repurchase intention among HMP users. The following proposition was proposed.

Proposition 2: CPV is positively related to repurchase intention.

\subsubsection{Customer loyalty}

Loyalty is defined as a commitment to repurchase or re-patronize a preferred product or service consistently. (Oliver, 1999: 34). Chahal \& Kumari (2011: 93) pointed out that customer loyalty reflected in two aspects, attitudinal and behavioral. It is more cost efficient to retain customers than to attract new customers (Chang et al., 2014), justifying the importance of focusing on customers who have ever used HMP. Higher value helps in generating customer satisfaction, loyalty and re-patronage intentions (Atulkar \& Kesari, 2017). Satisfied customers were willing to buy more and were more loyal to the company (Chiu et al., 2014). Therefore, CPV directly and significantly influences customer loyalty (Gallarza et al., 2016).

Past studies confirmed that three value dimensions (FV, SV and EV) were significantly related to loyalty (Gallarza et al., 2016; Koller, et al., 2011; Seyal et al., 2014; Gallarza et al., 2015). Carlson et al. (2015) also reported that the formative construct of CPV (FVP, FVQ and EV dimensions only) were significantly related to customer loyalty. CV was only tested in Seyal et al. (2014), but the relationship between CV and loyalty was not significant. This might be due to the conditional factors applied in their study, which were perceived as less important by respondents and thus not valued. This study proposed to test the influence of second-order formative CPV, with FVP, FVQ, SV, EV, and CV as the first-order, on customer loyalty for HMP. The following proposition was proposed.

Proposition 3: CPV is positively related to customer loyalty. 


\section{Conceptual Framework and Research Propositions Development}

Following the discussion on variables relationships, the conceptual framework is presented in Figure 1 . The independent variables were second-order CPV and its five first-order value dimensions (FVP, FVQ, SV, EV and $\mathrm{CV})$. The dependent variables were repurchase intention and customer loyalty. P1-P3 represent the propositions generated in this study.

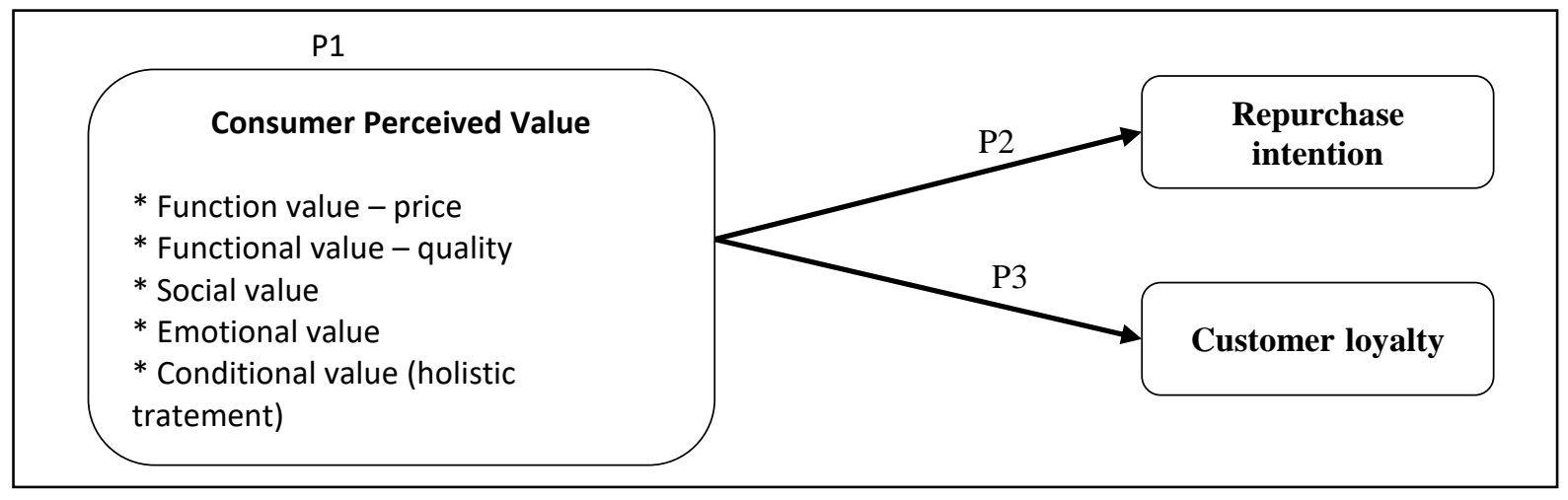

Figure 1 Conceptual framework

\section{Limitation and Conclusion}

This study's framework provides new insight in HMP consumption behavior by focusing on the influence of CPV on repurchase intention and customer loyalty. Underline by TCV, this study theoretically contributes to the literature by proposing CPV value dimensions (FVP, FVQ, SV, EV, and CV) specifically for HMP, in which CV tested holistic treatment value among consumers. This study framework could be applied in cross-sectional study to investigate HMP consumption.

This study enables industry practitioners to better understand consumer purchase behaviors and capitalize on the growing interest of consumers in HMP marketing. Information on CPV allows marketers to better plan promotion strategies and product design. In line with the large and increasing consumption of HMP by consumers, knowing the CPV will allow marketers to produce the HMP required by consumers. Besides that, understanding CPV influences will allow marketers to plan strategies to retain existing customers.

\section{References}

Ajzen, I. (1991). The Theory of Planned Behavior. Oranizational Behavior and Human Decision Processes, 50, 179-211.

Atulkar, S., \& Kesari, B. (2017). Satisfaction, loyalty and repatronage intentions: Role of hedonic shopping values. Journal of Retailing and Consumer Services, 39(January), $23-34$. https://doi.org/10.1016/j.jretconser.2017.06.013

Carlson, J., O'Cass, A., \& Ahrholdt, D. (2015). Assessing customers' perceived value of the online channel of multichannel retailers: A two country examination. Journal of Retailing and Consumer Services, 27, 90102. https://doi.org/10.1016/j.jretconser.2015.07.008

Carlson, J., Rosenberger, P. J., \& Rahman, M. M. (2016). A hierarchical model of perceived value of grouporiented travel experiences to major events and its influences on satisfaction and future group-travel intentions. Journal of Travel \& Tourism Marketing, 33(9), 1251-1267. https://doi.org/10.1080/10548408.2015.1117407

Chahal, H., \& Kumari, N. (2011). Consumer perceived value and consumer loyalty in the healthcare sector. Journal of Relationship Marketing, 10(88), 88-112. https://doi.org/10.1080/15332667.2011.577729

Chang, L., Backman, K. F., \& Huang, Y. C. (2014). Creative tourism: a preliminary examination of creative tourists' motivation, experience, perceived value and revisit intention. International Journal of Culture, Tourism and Hospitality Research, 8(4), 401-419. https://doi.org/10.1108/IJCTHR-04-2014-0032

Chang, M.-Y., Liu, C.-Y., \& Chen, H.-Y. (2014). Changes in the use of complementary and alternative medicine in Taiwan: A comparison study of 2007 and 2011. Complementary Therapies in Medicine, 22(3), 489-99. https://doi.org/10.1016/j.ctim.2014.03.001

Charaf, S., Wardle, J. L., Sibbritt, D. W., Lal, S., \& Callaway, L. K. (2015). Women's use of herbal and alternative medicines for preconception care. Australian and New Zealand Journal of Obstetrics and Gynaecology, 
55(3), 222-226. https://doi.org/10.1111/ajo.12324

Chiu, C.-M., Wang, E. T. G., Fang, Y.-H., \& Huang, H.-Y. (2014). Understanding customers' repeat purchase intentions in $\mathrm{B} 2 \mathrm{C}$ e-commerce: The roles of utilitarian value, hedonic value and perceived risk. Information Systems Journal, 24(1), 85-114. https://doi.org/10.1111/j.1365-2575.2012.00407.x

Choi, E., Ko, E., \& Kim, A. J. (2016). Explaining and predicting purchase intentions following luxury-fashion brand value co-creation encounters. Journal of Business Research, 69, 5827-5832. https://doi.org/10.1016/j.jbusres.2016.04.180

Craft, R., McClure, K. C., Corbett, S., Ferreira, M. P., Stiffarm, A. M., \& Kindscher, K. (2015). Ethnic differences in medicinal plant use among university students: A cross-sectional survey of self-reported medicinal plant use at two Midwest Universities. BMC Complementary and Alternative Medicine, 15, 192. https://doi.org/10.1186/s12906-015-0725-1

Dodds, S., Bulmer, S., \& Murphy, A. (2014). Consumer value in complementary and alternative medicine (CAM) health care services. Australasian Marketing Journal, 22(3), 218-229. https://doi.org/10.1016/j.ausmj.2014.08.004

Du, Y., Wolf, I.-K., Zhuang, W., Bodemann, S., Knöss, W., \& Knopf, H. (2014). Use of herbal medicinal products among children and adolescents in Germany. BMC Complementary and Alternative Medicine, 14, 218. https://doi.org/10.1186/1472-6882-14-218

Duffy, G. F., Shupe, E. S., Kuczmarski, M. F., Zonderman, A. B., \& Evans, M. K. (2017). Motivations for botanical use by socioeconomically diverse, urban adults: Does evidence support motivation? The Journal of Alternative and Complementary Medicine, 23(10), 812-818. https://doi.org/10.1089/acm.2016.0224

Fishbein, M., \& Ajzen, I. (1975). Belief, Attitude, Intention and Behavior: An Introduction to Theory and Research. Reading, MA: Addison-Wesley.

Gallarza, M. G., Arteaga-Moreno, F., Chiappa, G. Del, \& Gil-saura, I. (2016). Intrinsic value dimensions and the value-satisfaction-loyalty chain : a causal model for services. Journal of Services Marketing, 30(2), 165185. https://doi.org/10.1108/JSM-07-2014-0241

Gallarza, M. G., Arteaga, F., Chiappa, G. Del, \& Gil-saura, I. (2015). Value dimensions in consumers' experience: Combining the intra- and inter-variable approaches in the hospitality sector. International Journal of Hospitality Management, 47, 140-150.

Gallarza, M. G., \& Gil-saura, I. (2006). Value dimensions, perceived value, satisfaction and loyalty: An investigation of university students' travel behaviour. Tourism Management, 27, 437-452.

Ganasegeran, K., Rajendran, A. K., \& Al-Dubai, S. A. R. (2014). Psycho-socioeconomic factors affecting complementary and alternative medicine use among selected rural communities in Malaysia: A crosssectional study. PLoS ONE, 9(11). https://doi.org/10.1371/journal.pone.0112124

Ghazali, E., Soon, P. C., Mutum, D. S., \& Nguyen, B. (2017). Health and cosmetics: Investigating consumers' values for buying organic personal care products. Journal of Retailing and Consumer Services, 39, 154163. https://doi.org/10.1016/j.jretconser.2017.08.002

Goh, T. T., Suki, N. M., \& Fam, K. (2014). Exploring a consumption value model for Islamic mobile banking adoption. Journal of Islamic Marketing, 5(3), 344-365. https://doi.org/10.1108/JIMA-08-2013-0056

Gonçalves, H. M., Lourenço, T. F., \& Silva, G. M. (2016). Green buying behavior and the theory of consumption values: A fuzzy-set approach. Journal of Business Research, 69, 1484-1491. https://doi.org/10.1016/j.jbusres.2015.10.129

Hellier, P. K., Geursen, G. M., Carr, R. A., \& Rickard, J. A. (2003). Customer repurchase intention: A general structural equation model. European Journal of Marketing, 37(11/12), 1762-1800. https://doi.org/10.1108/03090560310495456

Hexa Research. (2017). Herbal Medicine Market Size and Forecast, by Product (Tablets \& Capsules, Powders, Extracts), by Indication (Digective Disorders, Respiratory Disorders, Blood Disorders), and Trend Analysis, 2014-2024.

Holbrook, M. B. (1999). Introduction to consumer value. In M. B. Holbrook (Ed.), Consumer Value: A Framework for Analysis and Research (First, pp. 1-28). London: Routledge.

Institute for Public Health (IPH). (2015). Volume IV: Traditional \& Complementary Medicine. (Intergovernmental Panel on Climate Change, Ed.), National Health \& Morbidity Survey 2015. Cambridge: Cambridge University Press.

Jarvis, C. B., Mackenzie, S. B., \& Podsakoff, P. M. (2003). A critical review of construct indicators and measurement model misspecification in marketing and consumer research. Journal of Consumer Research, 30, 199-218.

Khan, S. N., \& Mohsin, M. (2017). The power of emotional value: Exploring the effects of values on green product 
consumer choice behavior. Journal of Cleaner Production, 150, 65-74. https://doi.org/10.1016/j.jclepro.2017.02.187

Kim, H. W., Gupta, S., \& Koh, J. (2011). Investigating the intention to purchase digital items in social networking communities: A customer value perspective. Information and Management, 48, 228-234. https://doi.org/10.1016/j.im.2011.05.004

Koller, M., Floh, A., \& Zauner, A. (2011). Further insights into perceived value and consumer loyalty: A green perspective. Psychology \& Marketing, 28(12), 1154-1176. https://doi.org/10.1002/mar

Kunkel, T., Doyle, J. P., \& Berlin, A. (2017). Consumers' perceived value of sport team games-A multidimensional approach. Journal of Sport Management, 31(1), 80-95. https://doi.org/10.1123/jsm.20160044

Leroi-Werelds, S., Streukens, S., Brady, M. K., \& Swinnen, G. (2014). Assessing the value of commonly used methods for measuring customer value: A multi-setting empirical study. Journal of the Academy of Marketing Science, 42(4), 430-451. https://doi.org/10.1007/s11747-013-0363-4

Lin, P.-C., \& Huang, Y.-H. (2012). The influence factors on choice behavior regarding green products based on the theory of consumption values. Journal of Cleaner Production, 22, 11-18. https://doi.org/10.1016/j.jclepro.2011.10.002

Oliver, R. L. (1999). Whence Consumer Loyalty? Journal of Marketing, 63, 33-44.

Örgev, C., \& Bekar, T. (2013). Non-Monetary Costs , Hospital Perceived Value and Patient Satisfaction in Health Institutions. International Journal of Alanya Faculty of Business, 5(2), 87-97.

Pevec, T., \& Pisnik, A. (2016). Perceived value of health service - The conceptual model. China-USA Business Review, 15(2), 80-87. https://doi.org/10.17265/1537-1514/2016.02.004

Posadzki, P., Watson, L. K., Alotaibi, A., \& Ernst, E. (2013). Prevalence of use of complementary and alternative medicine ( CAM ) by patients/consumers in the UK: Systematic review of surveys. Clinical Medicine, 13(2), 126-131.

Rezai, G., Mohamed, Z., Shamsudin, M. N., \& Zahran, M. Z. (2013). Effect of consumer demographic factors on purchasing herbal products online in Malaysia. International Journal of Social, Behavioral, Educational, Economics and Business Industrial Engineering, 7(8), 2380-2386.

Rhee, T. G., Ng, J. Y., \& Dusek, J. A. (2017). Utilization and perceived benefits of homeopathy and herbal therapies in U.S. adults: Implications of patient-centered care. Complementary Therapies in Clinical Practice, 29, 9-15. https://doi.org/10.1016/j.ctcp.2017.07.003

Seyal, A., Rahman, M. N. A., Rahman, A. A., \& Ramlie, R. E. (2014). A study of Bruneian customers use of mobile services: Examining Theory of Consumption Value with customers loyalty. In 25th Australasian Conference on Information Systems. Auckland.

Sheth, J. N., Newman, B. I., \& Gross, B. L. (1991). Why we buy what we buy: A Theory of Consumption Values. Journal of Business Research, 22, 159-170. https://doi.org/10.1016/0148-2963(91)90050-8

Suki, N. M. (2016). Consumer environmental concern and green product purchase in Malaysia: structural effects of consumption values. Journal of Cleaner Production, 132, 204-214. https://doi.org/10.1016/j.jclepro.2015.09.087

Sweeney, J., \& Soutar, G. (2001). Consumer perceived value: the development of a multiple item scale. Journal of Retailing, 77(2), 203-220. https://doi.org/10.1016/S0022-4359(01)00041-0

Tangkiatkumjai, M., Boardman, H., Praditpornsilpa, K., \& Walker, D.-M. (2014). Reasons why Thai patients with chronic kidney disease use or do not use herbal and dietary supplements. BMC Complementary and Alternative Medicine, 14(1), 473. https://doi.org/10.1186/1472-6882-14-473

Wang, H.-Y., Liao, C., \& Yang, L.-H. (2013). What affects mobile application use? The roles of consumption values. International Journal of Marketing Studies, 5(2), 11-22. https://doi.org/10.5539/ijms.v5n2p11

Willems, K., Leroi-Werelds, S., \& Swinnen, G. (2016). The impact of customer value types on customer outcomes for different retail formats. Journal of Service Management, 27(4), 519-618. https://doi.org/10.1108/JOSM-11-2015-0364

Woodruff, R. B. (1997). Customer value: The next source for competitive advantage. Journal of the Academic of Marketing Science, 25(2), 139-153.

Wu, C.-H., Wang, C.-C., \& Kennedy, J. (2013). The prevalence of herb and dietary supplement use among children and adolescents in the United States: Results from the 2007 National Health Interview Survey. Complementary Therapies in Medicine, 21, 358-363.

Yang, H.-L., \& Lin, R. (2017). Determinants of the intention to continue use of SoLoMo services: Consumption values and the moderating effects of overloads. Computers in Human Behavior, 73, 583-595. https://doi.org/10.1016/j.chb.2017.04.018 
Yang, J., Ma, J., Arnold, M., \& Nuttavuthisit, K. (2018). Global identity, perceptions of luxury value and consumer purchase intention: a cross-cultural examination. Journal of Consumer Marketing. https://doi.org/10.1108/JCM-02-2017-2081

Zainuddin, N., Tam, L., \& McCosker, A. (2016). Serving yourself: Value self-creation in health care service. Journal of Services Marketing, 30(6), 586-600. https://doi.org/10.1108/JSM-02-2016-0075

Zeithaml, V. A. (1988). Consumer perceptions of price, quality, and value: A means-end model and synthesis of evidence. Journal of Marketing, 52(3), 2-22. 